\title{
Implementation of Semarang City Spatial Plan
}

\author{
Cahyo Adhi Widodo ${ }^{1}$, Kismartini ${ }^{2}$ \\ \{cahyo86@rocketmail.com¹,kis_martini@yahoo.co.id ${ }^{2}$ \} \\ Universitas Diponegoro, Indonesia ${ }^{1,2}$
}

\begin{abstract}
Urban Land use Plan of Semarang need to be studied further to see location of demographic Semarang City which make Semarang City developed become city that focusing on trade and service, and density of population of Semarang City which increasingly dense every year, in order to make Semarang City as center of international trade and service that is safe, convenient, productive, and sustainable. However, various strategic issues that developed are the high land conversion, the illegal construction of illegal buildings and the placement of development status that is not in accordance with the spatial layout of Semarang City Government, as happened in Genuk Subdistrict, the development of industrial number in Genuk resulted in the increasing of industrial activity that have impact on environmental quality, industrial pollution cases can also be attributed to a lack of knowledge of waste treatment. Therefore, this study aims to find out the implementation of Urban Planning and Regional Planning of Semarang city as well as the driving factors and inhibiting factors faced by Semarang City Government in implementing Urban Plans and Regional Plans of Semarang City.
\end{abstract}

Keywords: Implementation, Urban Planning, Communication.

\section{Introduction}

The city of Semarang has a strategic geographic position because it is located in the economic traffic lane of the island of Java, and is a Central Java development corridor consisting of four gates, namely the North coast corridor; South corridor towards dynamic cities such as Magelang Regency, Surakarta which is known as Merapi-Merbabu corridor, East corridor towards Regency.

Demak/Grobogan; and west towards Kendal Regency. In the development and growth of Central Java, Semarang is very instrumental especially with the presence of ports, land transport networks (rail and road lines) and air transport which is a potential for the transportation hub of the Central Java Regional and Central Java Regional Transit Cities. Demographic data for 2016 shows that the highest density is located in Pedurungan subdistrict which reaches 187,174 inhabitants. With such a population density, it requires sufficient space to provide public facilities and services. Therefore, there is a need for a sustainable spatial plan to anticipate various problems that arise in the future. For this reason, a regional arrangement is needed with a purpose. The aim of Spatial Planning is to realize Semarang City as a safe, comfortable, productive and sustainable international scale trade and service center. According to the Law of the Republic of Indonesia Number 26 Year 2007 concerning Spatial Planning explains several things that need to be considered in spatial planning in Regencies or Cities [1]. 
In line with this law, the city of Semarang conducts Regional Spatial Planning which is adjusted to the Semarang City Long-Term Development Plan. Regional Spatial Planning aims to direct strategic development in spatial use, in addition to the preparation of inter-regional development spatial planning more harmonious, and also made guidelines in investment by the community, other governments and the private sector.

\section{Research Method}

The research method used in this study is to use a qualitative approach to explain the research conducted in more depth [2]. The research site is the place or region where the research will be carried out. This study has the focus of the study to be examined is the implementation of the Semarang City Spatial Plan. While the locus of this research is the main target of the BWK IV Semarang City, more precisely in the Semarang Genuk area. Data collection techniques in this study were by interview and documentation, and as speakers were the Spatial Planning Office, Members of the Semarang City DPRD, and the community.

\section{Result and Discussion}

Based on Law Number 26/2007 that Spatial Planning is a process system that includes spatial planning, spatial use, and spatial use control, whereas spatial planning itself is a structural manifestation and spatial use pattern [1]. Sustainable spatial planning is planning, utilization and control of space by dissolving environmental aspects in its consideration.

Urban spatial planning is important to be held, given the increasing human activities in urban areas that cause various environmental problems such as air pollution, land subsidence, flooding, rob and so on [3][4]. Based on Law Number 26/2007 article 11 concerning the authority of regency/city governments has the function as a regulator, guidance and supervision of the implementation of spatial planning. Related to Law Number 26 of 2007, the Semarang City Government made Semarang City Regulation Number 14 of 2011 concerning Semarang City Spatial and Regional Planning [5]. The policy was made to regulate the existing spatial patterns in the city of Semarang. In the regulation to make Semarang City a safe, comfortable, productive and sustainable international scale trade and service center.

The results of the interviews conducted, that the existence of spatial planning in the city of Semarang has been able to solve the problems that exist in the city of Semarang. Because the function of spatial planning is as a guideline for spatial planning in the City of Semarang, by successfully solving the problems that exist in the City of Semarang more precisely in the spatial planning section, it is not immune to several factors. Good communication between the government and the community and the private sector makes the existing spatial planning program easily run and there are not many obstacles. With good education going on, it requires human resources to be able or able to master the things that are important to run the program that will run. Because human resources become very important for success in problem solving. The results of observations, interviews and theories that institutions are authorized to realize the Regional Regulation on Regional Spatial Planning. Which is where the institutions to make these regulations require the process of making them by referring to the Law and Ministerial Decree. 
The program targets are carried out throughout the city of Semarang. From the results of the interview that the current target is in accordance with the local regulation. Because the target itself has been set at the Perda. With the existence of BWK (part of the city area) it is sufficient to set program objectives. So, in each region it has its own zone, for example in the Tembalang area, that area becomes the education and catchment area. Another example in the Genuk and Semarang areas of the west, the area became part of the area related to industry. So, the target of the existing program is very precise and runs well because it is in accordance with the regulations.

\section{Conclusion}

Regional spatial planning in Semarang City is a form of Semarang City government program in advancing Semarang City in accordance with existing objectives. That goal is the realization of Semarang City as a center for international scale trade and services that is safe, comfortable, productive, and sustainable.

The implementation of the Regional Spatial Plan in the City of Semarang is seen from the five exact things that need to be fulfilled in the effectiveness of a program implementation, namely the accuracy of the policy, in that the policy density has been running effectively and very well. Because the problem solving that has been solved with the character - the character of the problem in accordance with the character and in making this policy it has been very precise in its making, because it was made by the relevant institutions and by racing the previous law [6][7][8][9]. The accuracy of the implementation, the implementers of the spatial planning program have been prepared to run this program. Because in the city of Semarang, spatial planning has become one of the important things for the progress of the City of Semarang. With the importance of this spatial planning, the Spatial Planning Department itself is now independent, not becoming one with the Housing Department. And the involvement of the community is still not good, its participation in spatial planning is still reduced due to factors - one of which is poor communication. The accuracy of the target, in this case the accuracy of the target is very appropriate because the ignition of goals and targets is right and goes well. Environmental accuracy, the form of interaction that occurs is still very bad between the government and the community. Because there was a break in communication between the government and the community. This happened because of the lack of communication below, so from sub-districts or sub-districts it didn't go down directly to deliver the program to be implemented. The accuracy of the process, that the implementation of the regional spatial plan the program implementers are ready in running spatial plans in the City of Semarang. Basically, this program is proposed by agencies that are assembled and run by the Spatial Planning Office. So that all staff and employees involved already understand about the time of its implementation, regulations, and the main tasks of its function.

Factors that influence in the Implementation of Regional Spatial Planning in Semarang City, there are four factors, namely, Communication, in spatial plans in Semarang, communication factors become one of the obstacles for the progress of Semarang City. Because when viewed from the field, communication between the government and the community is still very poor. But the communication between related agencies has been going well. Resources, resources become one of the factors for this program. In this program, human resources are good enough to carry out their duties because the implementers have been prepared for this program. But in resources there is also one of the factors that inhibits 
financial resources, in the city of Semarang the APBD budget is blocked. Even though the budget becomes very important for the progress of a city. Disposition, in the implementation of spatial policy in the City of Semarang, implementers must understand the policies that have been made. Their attitude in responding to the policy must also be understood by an implementer so that they are guided by the existing provisions. If they cannot be guided by the existing guidelines there must be sanctions waiting for the next. In addition, implementing responsibilities in implementing from what they understand in the policy also become one of the factors for the success of an implementation. Bureaucratic structure, in this case the tasks and functions possessed by an organization will make the implementation process more effective or run according to the planned provisions. in Mayor Regulation Number 33 of 2008 concerning the duties and functions of the Spatial Planning Office. The spatial planning office itself has the task of carrying out regional government affairs in the field of urban planning based on the principle of autonomy and the task of supporting.

\section{References}

[1] "Undang-undang Republik Indonesia No. 26 Tahun 2007 Tentang Penataan Ruang." .

[2] L. J. Moleong, "Metodologi Penelitian Kualitatif (Edisi Revisi)," in PT. Remaja Rosda Karya, 2017.

[3] L. Hakim, "Pengantar Administrasi Pembangunan,” Yogyakarta: Ar-Ruzz Media, 2011.

[4] P. Hariyono and R. Indriani, Perencanaan pembangunan kota dan perubahan paradigma. Pustaka Pelajar, 2010.

[5] "Peraturan Pemerintah Kota Semarang Nomor 14 Tahun 2011 Tentang Rencana Tata Ruang Wilayah Kota Semarang Tahun 2011-2031.".

[6] S. Anggara, "Kebijakan Publik, Bandung," Penerbit CV Pustaka Setia, 2014.

[7] I. Dwiyanto, "Kebijakan Publik Berbasis Dynamic Policy Analisys," Gava Media Yogyakarta, 2009.

[8] S. Kusumanegara, Model dan aktor dalam proses kebijakan publik. Gava Media, 2010.

[9] R. Nugroho, "Public policy: Teori, manajemen, dinamika, analisis, konvergensi, dan kimia kebijakan,” Jakarta Elex Media Komputindo, 2014. 